\title{
Bioconversion of Palm Oil into Biosurfactant by Halomonas meridiana BK-AB4 for the Application of Corrosion Inhibitor
}

\author{
Ira Prima Sari, Muhammad Imam Basyiruddin, and Rukman Hertadi \\ Department of Chemistry, Institut Teknologi Bandung, Jl. Ganesha No. 10, Bandung 40132, Indonesia
}

Received July 28, 2017; Accepted October 24, 2017

\begin{abstract}
Biosurfactant is environmentally friendly surfactant produced by a certain microorganism in a lipid-rich medium. A previous study has shown that Halomonas meridiana BK-AB4 had the potential of a moderately halophilic bacterium in converting olive oil into biosurfactant. In the present study, the effect of changing the carbon source from olive oil into cheaper and more abundant vegetable oil, which is palm oil, for the production of the biosurfactant was evaluated. The study began by optimizing the production medium with varying the nitrogen source, the concentration of palm oil and $\mathrm{pH}$. The optimum condition of biosurfactant production was observed in the medium consisted of $0.6 \%(\mathrm{w} / \mathrm{v})$ of urea, $2 \%(\mathrm{~V} / \mathrm{v})$ of palm oil and $\mathrm{pH}$ 9. The resulted biosurfactant was stable at $\mathrm{pH} 7-10$ and in the salt concentration of 6-15\%. Biosurfactant activity in lowering air-water surface tension was measured using the Du Noüy ring method, and the value of critical micelle concentration (CMC) was about $233 \mathrm{ppm}$. At this point, the surface tension of water dropped from 68.3 to 49.8 dyne/cm. Preliminary structural analysis by using FTIR technique suggested that the resulted biosurfactant has $-\mathrm{OH},-\mathrm{C}-\mathrm{H}$ aliphatic $\mathrm{C}=\mathrm{C}, \mathrm{H}-\mathrm{C}-\mathrm{C}$ and $\mathrm{C}=\mathrm{O}$ groups in its structure, which is similar to that of the fatty-acid type of biosurfactant. The potential of biosurfactant as a metal corrosion inhibitor was evaluated by using electrochemical impedance spectroscopy (EIS) that measured at $30{ }^{\circ} \mathrm{C}$. The measurement revealed that the highest inhibition level was observed at the biosurfactant concentration about 200 ppm that corresponds to the inhibition level about 53.23\%.
\end{abstract}

Keywords: biosurfactant; Halomonas meridiana BK-AB4; corrosion inhibitor

\section{ABSTRAK}

Biosurfaktan adalah surfaktan ramah lingkungan yang diproduksi oleh mikroorganisme tertentu dalam media kaya lemak. Dalam studi sebelumnya, telah ditemukan potensi bakteri halofilik, Halomonas meridiana BK-AB4, dalam mengkonversi minyak zaitun ke biosurfaktan. Dalam penelitian ini dipelajari efek variasi sumber karbon dari minyak zaitun ke minyak yang lebih murah dan berlimpah, yaitu minyak sawit, untuk produksi biosurfaktan. Studi ini dimulai dengan mengoptimalkan produksi media pada berbagai sumber nitrogen, konsentrasi minyak sawit dan $\mathrm{pH}$. Kondisi optimum produksi biosurfaktan diamati dalam medium yang terdiri dari 0,6\% (b/v) urea, $2 \%(\mathrm{v} / \mathrm{v})$ minyak sawit dan $\mathrm{pH}$ 9. Produksi biosurfaktan stabil pada $\mathrm{pH}$ 7-10 dan konsentrasi garam 6-15\%. Aktifitas biosurfaktan dalam menurunkan tegangan permukaan air-air diukur menggunakan metode cincin Du Noüy, nilai konsentrasi Misel kritis (CMC) adalah sekitar 233 ppm. Pada titik ini, tegangan permukaan air menurun dari 68,3 ke 49.8 dyne/cm. Analisis awal struktur menggunakan teknik FTIR dihasilkan bahwa biosurfaktan memiliki gugus - $\mathrm{OH},-\mathrm{C}-\mathrm{H}$ alifatik $C=C, H-C-C$ dan $C=O$ dalam strukturnya, yang mirip dengan jenis asam lemak biosurfaktan. Potensi biosurfaktan sebagai inhibitor korosi logam dievaluasi menggunakan spektroskopi impedansi elektrokimia (EIS) yang diukur di $30^{\circ} \mathrm{C}$. Pengukuran menunjukkan bahwa tingkat inhibisi diamati pada konsentrasi biosurfaktan sekitar 200 ppm yang sesuai dengan tingkat inhibisi sekitar 53,23\%.

Kata Kunci: biosurfaktan; Halomonas meridiana BK-AB4; inhibitor korosi

\section{INTRODUCTION}

Steel is a material made from a mixture of iron and other elements (most is carbon) that are typically used for constructions, such as railways, bridges, equipment, and airport, because of its high mechanical strength [1]. Like a common metal, steel is still experiencing the process of corrosion. In order to slow down the corrosion

* Corresponding author.

Email address : rukman@chem.itb.ac.id rate, one effort is by adding corrosion inhibitors that can attach to the steel surface and prevent direct contact with corrosion agents [2-3]. One type of corrosion inhibitors is a surfactant that has a polar moiety that can strongly attach to the steel surface and hydrophobic tail that prevent polar corrosion agent to come into contact with the steel surface. Most surfactants, however, are petroleum derivates that

DOI: $10.22146 /$ ijc. 27040

Ira Prima Sari et al. 
typically not environmentally friendly [2,4]. The other alternative is the used of biosurfactant, which is surfactant produced by certain microorganisms that are cultivated in the lipid-rich medium. Biosurfactant has some advantages than the synthetic one, such as low toxicity, easier to decompose and reproducible [5-7]. In addition, biosurfactants have similar functions to surfactant synthetic. Hence they can be a better alternative $[2,8]$.

In this study, relatively abundant vegetable oil, which is palm oil, was used as a carbon source by a halophilic bacterium, Halomonas meridiana BK-AB4 to produce biosurfactant. The use of this bacterium as biosurfactant producer was based on the previous study that stated this bacterium was able to convert olive oil as biosurfactants (unpublished data). The used of palm oil instead of olive oil is because it is relatively more abundant and cheaper in Indonesia as the second largest palm oil producer country in the world. In this study, the optimization of a medium for the bacterial growth and biosurfactant production was also conducted. The physicochemical properties were also studied from the resulted biosurfactant. The potential of the biosurfactant as a corrosion inhibitor was evaluated by electrochemical impedance spectrophotometry (EIS). It is shown here that Halomonas meridian BK-AB4 is a potential biosurfactant producer for the corrosion inhibitor.

\section{EXPERIMENTAL SECTION}

\section{Materials}

Halomonas meridiana BK-AB4, which was indigenous from Bleduk Kuwu mud crater, Purwodadi, Central Java, was obtained from the collection of the biochemistry laboratory of ITB [9]. Inorganic salts, such as $\mathrm{NaCl}, \mathrm{NH}_{4} \mathrm{Cl}, \mathrm{CO}\left(\mathrm{NH}_{2}\right)_{2}, \mathrm{KCl}, \mathrm{MgSO}_{4}, \mathrm{CaCl}_{2} .2 \mathrm{H}_{2} \mathrm{O}$, $\mathrm{MgSO}_{4} .7 \mathrm{H}_{2} \mathrm{O}, \quad \mathrm{NaNO}_{3}, \quad \mathrm{KNO}_{3}, \quad \mathrm{FeSO}_{4} .7 \mathrm{H}_{2} \mathrm{O}$, $\mathrm{ZnSO}_{4} .7 \mathrm{H}_{2} \mathrm{O}, \mathrm{CuSO}_{4} .5 \mathrm{H}_{2} \mathrm{O}, \mathrm{MnSO}_{4} . \mathrm{H}_{2} \mathrm{O}, \mathrm{HCl}, \mathrm{NaOH}$, $\mathrm{K}_{2} \mathrm{HPO}_{4}, \mathrm{KH}_{2} \mathrm{PO}_{4}$, were purchased from Merck. Some organic solvent, such as chloroform, ethyl acetate, and methanol, were also purchased from Merck. Bacto agar, yeast extract, beef extract, peptone, and tryptone were purchased from Difco. The other chemical, such as methylene blue, and cetyltrimethylammonium bromide (CTAB), were purchased from Sigma/Aldrich. Palm oil was obtained from a local market.

\section{Procedure}

\section{Biosurfactant production}

H. meridiana was precultured at $37{ }^{\circ} \mathrm{C}$ in $5 \mathrm{~mL}$ Nutrient Broth medium containing 1\% (w/v) of peptone, $5 \%(\mathrm{w} / \mathrm{v}) \mathrm{NaCl}$, and $0.5 \%(\mathrm{w} / \mathrm{v})$ beef extract inside 150 rpm shaking incubator for $16 \mathrm{~h}$. As much as $1 \%$ of precultured was transferred into a production mineral salts medium (MSM) containing $0.19 \%(\mathrm{w} / \mathrm{v}) \mathrm{KH}_{2} \mathrm{PO}_{4}$, $0.13 \%(\mathrm{w} / \mathrm{v}) \mathrm{K}_{2} \mathrm{HPO}_{4}, 0.1 \%(\mathrm{w} / \mathrm{v}) \mathrm{MgSO}_{4} .7 \mathrm{H}_{2} \mathrm{O}, 0.001 \%$ (w/v) $\mathrm{CaCl}_{2} .2 \mathrm{H}_{2} \mathrm{O}, 0.001 \%$ (w/v) $\mathrm{FeSO}_{4} .7 \mathrm{H}_{2} \mathrm{O}, 0.1 \%$ $(\mathrm{w} / \mathrm{v})$ yeast extract, varied nitrogen source e.g. $\mathrm{NaNO}_{3}$, $\mathrm{KNO}_{3}, \mathrm{NH}_{4} \mathrm{Cl}, \mathrm{CO}\left(\mathrm{NH}_{2}\right)_{2}$, and palm oil as the carbon source. Then it was cultivated at $37^{\circ} \mathrm{C}$ for $78 \mathrm{~h}$ in the shaking incubator using $150 \mathrm{rpm}$ of the aeration rate. The culture and supernatant were separated by 6000 rpm centrifugation at $4{ }^{\circ} \mathrm{C}$ for $30 \mathrm{~min}$. The supernatant was subsequently treated by the addition of $1 \mathrm{M} \mathrm{NaOH}$ solution until pH 12 and then was incubated at $4{ }^{\circ} \mathrm{C}$ for $24 \mathrm{~h}$ to precipitate the biosurfactant. The biosurfactant suspension was collected from cell-free supernatant by $6000 \mathrm{rpm}$ centrifugation at $4^{\circ} \mathrm{C}$. The collected biosurfactant was purified by solving it with water and re-extracted with mix solvent of chloroform/methanol (3:2). The organic phase was separated, and the biosurfactant was collected by vacuum evaporation to remove the solvent.

\section{Oil spreading test}

To perform monitoring for the biosurfactant production progress, we carried it out by checking the biosurfactant activity with the method of oil spreading test (OST). This test was conducted by preparing an oil-water mixture by adding $1 \mathrm{~mL}$ of palm oil to $50 \mathrm{~mL}$ water in a petri dish. Biosurfactant activity was determined by dropping $10 \mu \mathrm{L}$ of biosurfactant solution onto the surface of the oil layer. The activity of the biosurfactant was exhibited by the formation of a clear zone on oil layer. The length of a diameter of the clear zone corresponds to the biosurfactant activity and its concentration.

\section{Measurement of emulsification activity}

The solution containing $5 \mathrm{~mL}$ of palm oil and $5 \mathrm{~mL}$ of supernatant were mixed in a test tube, and it was then vortexed at high speed for 2 min. The stability of the emulsification was evaluated by incubating the emulsified oil for $24 \mathrm{~h}$ at room temperature and then expressed it as an emulsification index $\left(\mathrm{El}_{24}\right)$, which was determined by measuring the height of the emulsion layer divided by the total height of the mixture and multiplied by 100 [10].

\section{Characterization of biosurfactant}

The biosurfactant was characterized by using Du Noüy tensiometer, Fourier transform infrared (FTIR) and electrochemical impedance spectroscopy (EIS). The critical micelle concentration (CMC) was determined at room temperature by measuring the biosurfactant surface tension with Du Noüy Ring method. The biosurfactant concentration was varied

Ira Prima Sari et al. 
from 45-195 mg/L. CMC was determined at the breakpoint in a plot of the surface tension of water versus biosurfactant concentrations [11]. The preliminary structural characterization was conducted with a spectroscopic method by using FTIR. The FTIR spectrum was measured from 500 to $4500 \mathrm{~cm}^{-1}$ to identify functional groups constitute the biosurfactant structure. The application of biosurfactant as inhibitor corrosion was studied by using electrochemical impedance spectroscopy (EIS) [12-13]. In this study, 1\% of $\mathrm{NaCl}$ solution was placed into an electrochemical cell and subsequently be saturated with $\mathrm{CO}_{2}$ for $30 \mathrm{~min}$. In addition, carbon, a saturated calomel, and platinum were used in this study as a working, a reference, and auxiliary electrodes, respectively.

\section{RESULT AND DISCUSSION}

\section{Optimization of Biosurfactant Production}

Production of biosurfactant is typically affected by carbon and nitrogen sources, $\mathrm{pH}$ and the salinity of the medium [6]. In this study, palm oil was used as the main carbon source, while for the nitrogen source, it was varied to obtain the optimum production of biosurfactant by $H$. meridiana BK-AB4. In this optimization stage, oil spreading test (OST) was employed to monitor the biosurfactant production.

Prior to the optimization, the growth and biosurfactant production curves to determine the optimum time for $H$. meridiana BK-AB4 in producing biosurfactant was generated. The bacterial inoculum was grown in MSM at $37^{\circ} \mathrm{C}$ under the shaking rate of $150 \mathrm{rpm}$ for $78 \mathrm{~h}$. In the course of growing period, the number of the cell was monitored by measuring the optical density by UV-Vis spectrophotometer at $600 \mathrm{~nm}$. The surfactant production was checked by OST method. The growth rate of the bacteria was highest during the first $72 \mathrm{~h}$ of incubation, but after that, it was gradually declining (Fig. 1). The highest biosurfactant production occurred at $50^{\text {th }} \mathrm{h}$ of the cultivation time, which is in the middle of log phase of the bacterial growth. Thus, in the next work, this cultivation time was used as the reference to harvest biosurfactant.

In the nitrogen source optimization, three different nitrogen-containing substances, which were $\mathrm{KNO}_{3}$, $\mathrm{NH}_{4} \mathrm{Cl}$, and urea, with the concentration of $0.6 \%(\mathrm{w} / \mathrm{v})$ were used. OST result showed urea as the best nitrogen source for the production of the biosurfactant (Fig. 2). The diameter of oil spreading higher than $1 \mathrm{~cm}$ was only provided by urea, while the other two only resulted in the diameter below $1 \mathrm{~cm}$. It is likely that nitrate and ammonium ions were somewhat toxic to the bacteria or might inhibit the biosynthesis of biosurfactant.
Table 1. Table of biosurfactant production

\begin{tabular}{rcc}
\hline Time & $\begin{array}{c}\text { Optical } \\
\text { Density }\end{array}$ & $\begin{array}{c}\text { Oil Spreading } \\
\text { Diameter }\end{array}$ \\
\hline 0 & 0.00 & 0.00 \\
12 & 0.12 & 0.55 \\
24 & 0.22 & 0.83 \\
36 & 0.44 & 1.60 \\
48 & 0.71 & 2.30 \\
60 & 0.91 & 2.10 \\
72 & 1.13 & 0.85 \\
74 & 1.17 & 0.85 \\
75 & 1.19 & 0.83 \\
76 & 1.21 & 0.83 \\
77 & 1.20 & 0.83 \\
78 & 1.19 & 0.85 \\
80 & 1.19 & 0.89 \\
84 & 1.17 & 0.90 \\
\hline
\end{tabular}

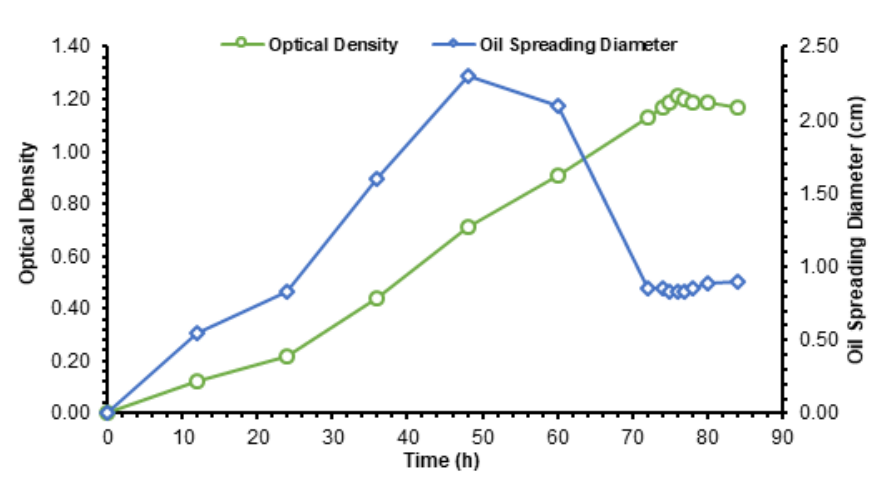

Fig 1. Growth and biosurfactant production curves of $H$. meridiana BK-AB4 in the minimum salt medium

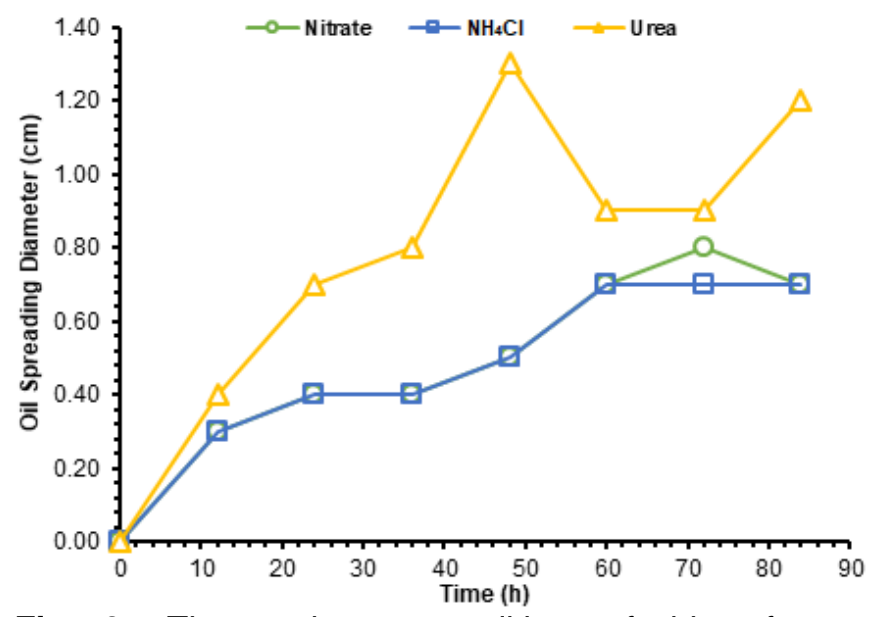

Fig 2. The optimum condition of biosurfactant production in the various nitrogen source

By using $0.6 \%(\mathrm{w} / \mathrm{v})$ urea as a nitrogen source, the concentration of palm oil as a carbon source was optimized. The palm oil concentration was varied from $2-10 \%(\mathrm{v} / \mathrm{v})$ and the biosurfactant production was monitored by OST. The result showed that $2 \%(\mathrm{v} / \mathrm{v})$ palm oil gave the longest diameter of oil spreading 


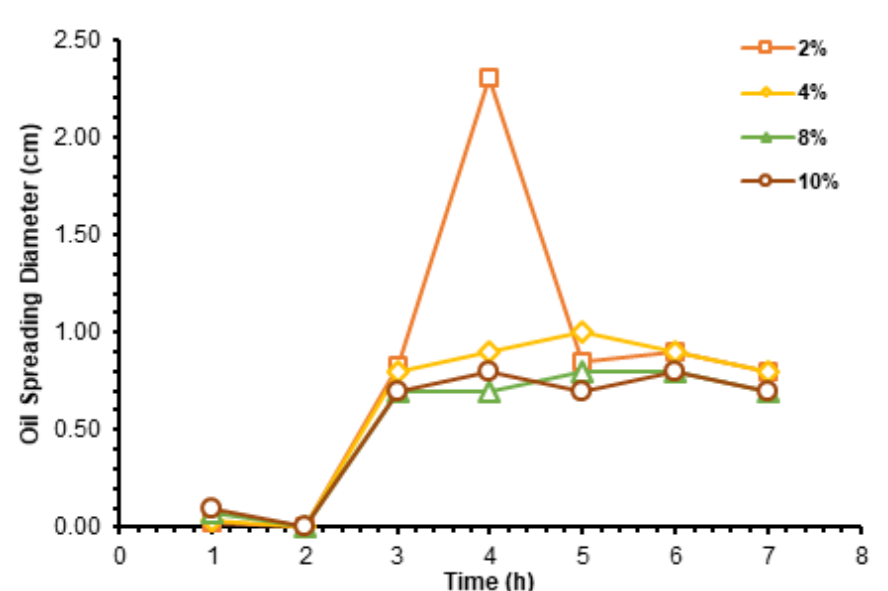

Fig 3. The optimum condition of biosurfactant production in the various concentration of palm oil

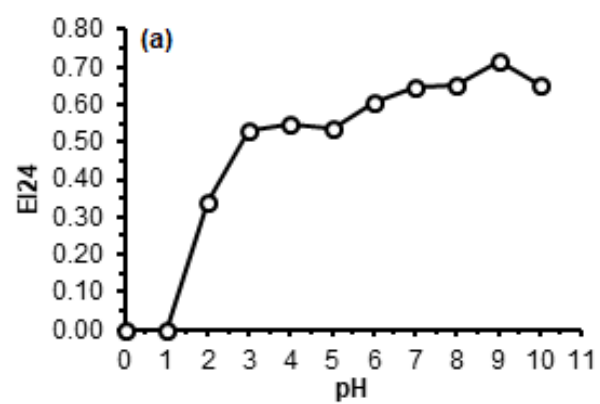

Fig 5. The optimum condition of biosurfactant in emulsification test in various $\mathrm{pH}$ (a) and $\mathrm{NaCl}$ concentration (b)

compared to the other concentrations (Fig. 3). The commercial palm oil used in this experiment contains many types of a fatty acid constituent that may not be compatible with growth and biosurfactant production.

Further optimization was varying $\mathrm{pH}$ of the production medium by using the optimized nitrogen and carbon sources. The range of medium $\mathrm{pH}$ was set from 4 to 10 . The biosurfactant production by $H$. meridiana BK-AB4 was also monitored by OST. The result revealed that $\mathrm{pH} 9$ gave the longest diameter of oil spreading (Fig. 4), suggesting that the biosurfactant production reached the highest yield in the alkaline condition. Most surfactants produced by halophilic bacteria exhibited high yield production in the alkaline condition, such as low halophilic Pseudomonas stutzeri which have the highest production of biosurfactant at $\mathrm{pH}$ 12 [14]. Based on the optimization result above, production of biosurfactants by $\mathrm{H}$. meridiana BK-AB4 for the next cycle of production was performed in the MSM media containing $0.6 \%(\mathrm{w} / \mathrm{v})$ urea, $2 \%(\mathrm{v} / \mathrm{v})$ palm oil and pH 9.

\section{Potential of Biosurfactant as an Emulsifier}

To evaluate the potential of biosurfactant produced by $H$. meridiana BK-AB4 as an emulsifier, an

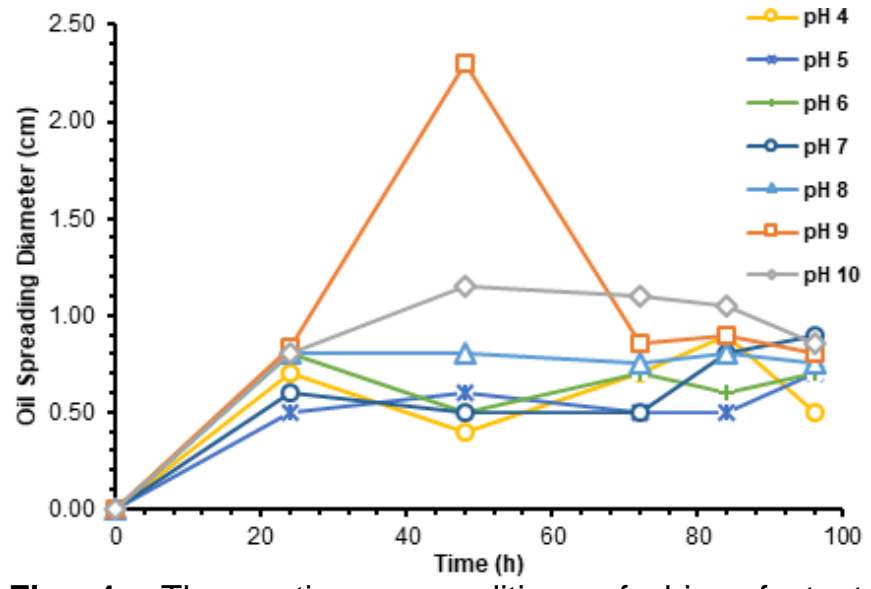

Fig 4. The optimum condition of biosurfactant production in the various $\mathrm{pH}$

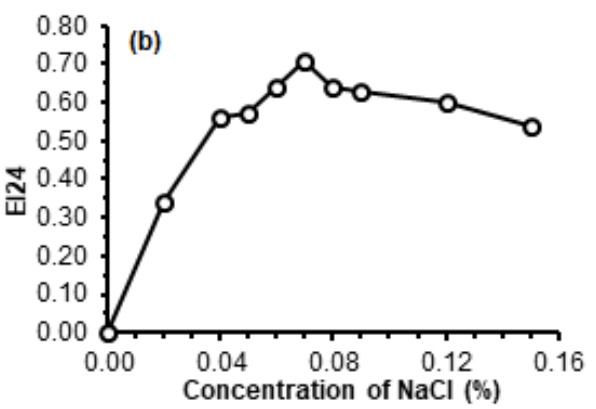

emulsification test was performed at different $\mathrm{pH}$ and $\mathrm{NaCl}$ concentrations. The emulsification activity was expressed as an emulsification index $\left(\mathrm{El}_{24}\right)$, which shows the ability of biosurfactant in maintaining the emulsion in $24 \mathrm{~h}$. The result showed that the highest $\mathrm{El}_{24}$ value was achieved when the emulsification was performed at $\mathrm{pH} 9$ and $7 \%(\mathrm{w} / \mathrm{v}) \mathrm{NaCl}$ (Fig. 5). At this optimum conditions, $\mathrm{El}_{24}$ reached about $75 \%$. However, the stable emulsion was observed within the wide range of $\mathrm{pH}$ and $\mathrm{NaCl}$, in which between $\mathrm{pH} 3-10$ and $\mathrm{NaCl}$ concentrations of $5-15 \%(\mathrm{w} / \mathrm{v})$. Such wide range of stability is suitable for many applications, such as food emulsifier, enhanced oil recovery, and corrosion inhibitor.

\section{Characterization of Biosurfactant}

The sample was characterized using an FTIR spectrophotometer to elucidate the structure of biosurfactant. The obtained FTIR spectrum revealed the presence of functional groups which is identical to the functional groups of biosurfactant. In this spectrum, $\mathrm{O}-\mathrm{H}$ group, aliphatic $\mathrm{CH}$ group, $\mathrm{C}=\mathrm{O}$ stretch from ester, and $\mathrm{C}=\mathrm{C}$ stretch was observed at a wave number of 3423, 2922, 1745 and $1520 \mathrm{~cm}^{-1}$, respectively (Fig. 6). Based on this spectral profile, the biosurfactant produced 


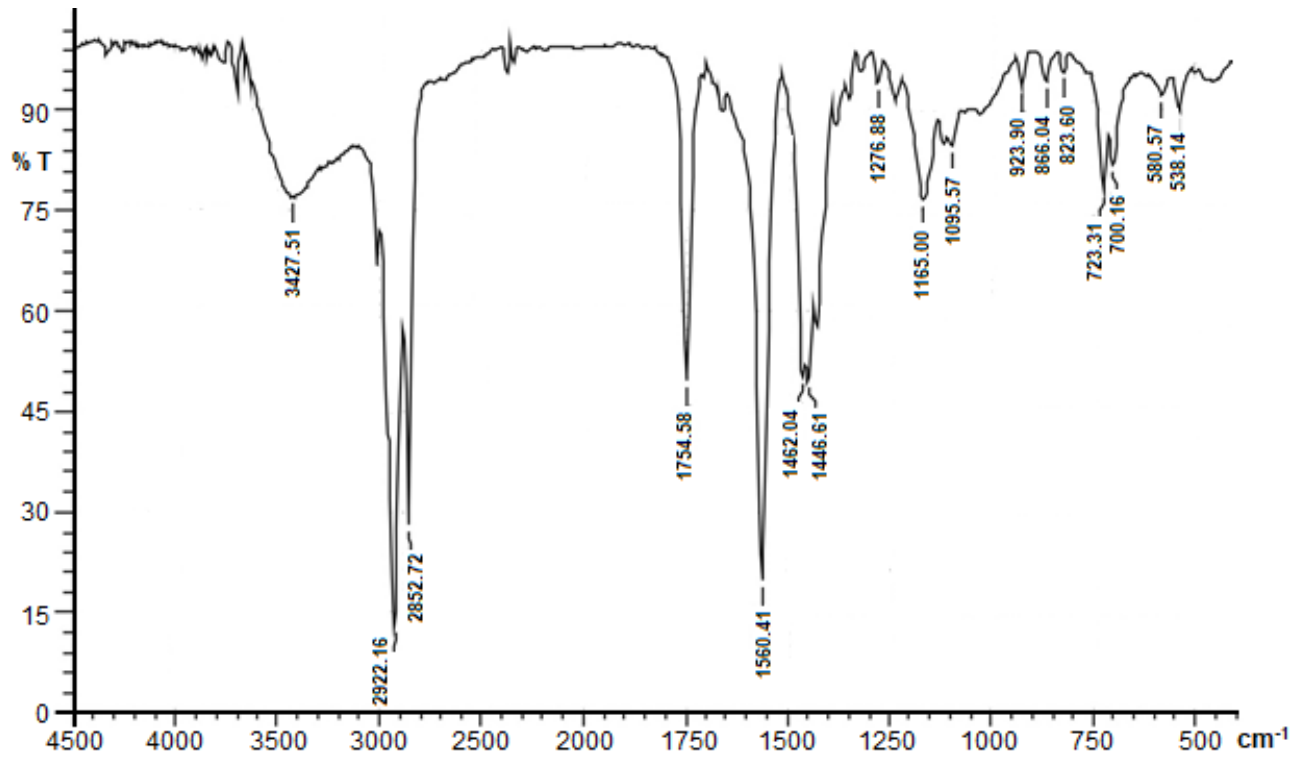

Fig 6. FTIR spectra of biosurfactant

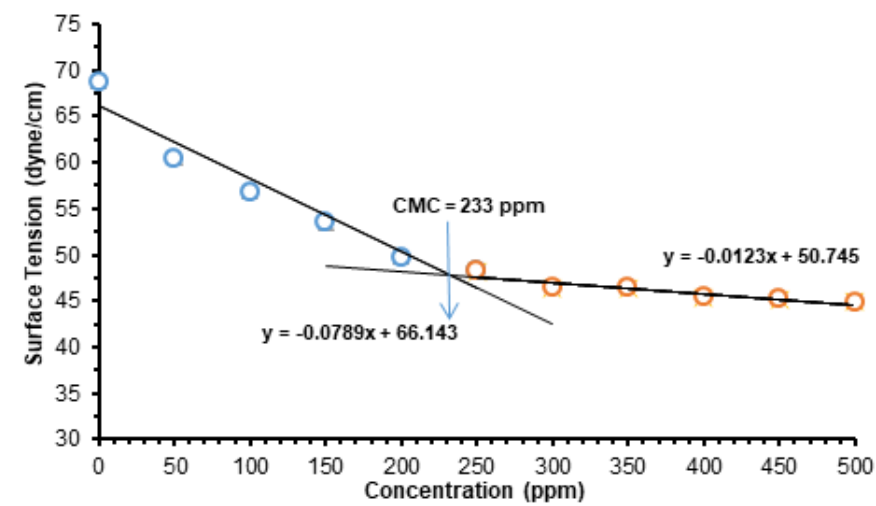

Fig 7. Determination of critical micelle concentration for biosurfactant produced by $\mathrm{H}$. meridiana BK-AB 4

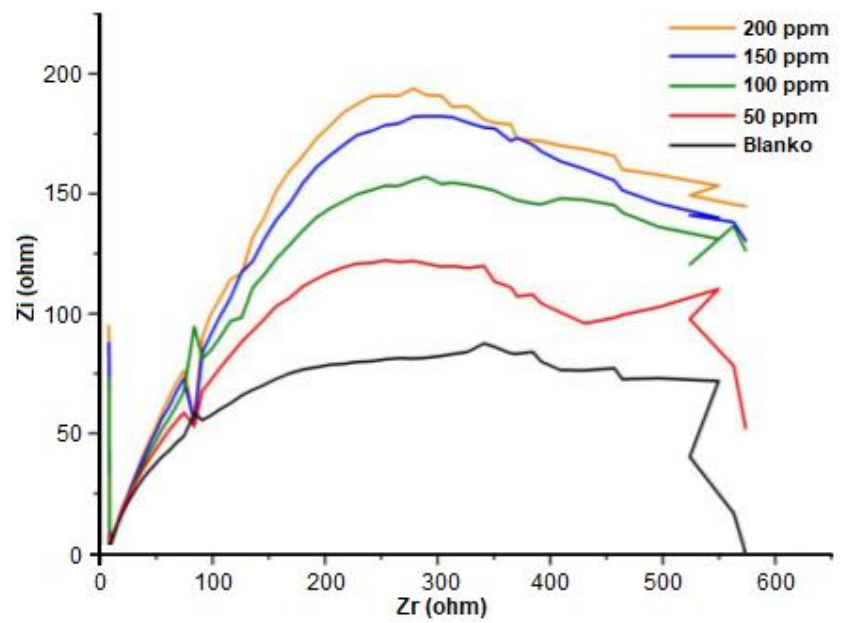

Fig 8. The Nyquist curve of corrosion inhibition activity in various concentration of biosurfactant that generated by electrochemical impedance spectrophotometer at $30^{\circ} \mathrm{C}$ by $H$. meridiana BK-AB4 showed similarity to the fatty acid group [15].

\section{Physicochemical Property of Biosurfactant and Its Application as a Corrosion Inhibitor}

In this study, physicochemical property of the biosurfactant produced by $\mathrm{H}$. meridiana BK-AB4 was studied based on its ability to lowering the surface tension of water. Du Noüy tensiometer was employed to measure the value of surface tension of water containing a various concentration of biosurfactant. This measurement showed that the surface tension decreased almost linearly by the increasing of biosurfactant concentration up to the concentration of $200 \mathrm{ppm}$, but after that, the addition of biosurfactant was not significantly lowered the surface tension (Fig. 7). The concentration at which the addition of biosurfactant does not further lower the surface tension of water is called as a critical micelle concentration (CMC). The value of CMC of the biosurfactant is 233 $\mathrm{ppm}$, in which at this concentration the surface tension of water decreased up to $18.7 \mathrm{dyne} / \mathrm{cm}$. Since the surface tension of water can be lowered by more than 10 dyne/cm, then $H$. meridiana BK-AB 4 can be classified as the potential biosurfactant producer $[11,16]$.

One of the applications of biosurfactant that sensitive to the $C M C$ value is a corrosion inhibitor. Limit of the effectiveness of biosurfactant as a corrosion inhibitor is CMC because, at the concentration above the CMC, the addition of biosurfactant is no longer effective to increase the inhibition level [12]. In this study, the potential of biosurfactant as the corrosion 
inhibitor was evaluated by Electrochemical Impedance Spectroscopy (EIS) method. Based on EIS measurement:

$\% E I=\frac{\left(R_{p_{\text {inhibited }}}-R_{p_{\text {blanko }}}\right)}{R_{p_{\text {inhibited }}}} \times 100 \%$

The highest efficiency of inhibition was observed at the biosurfactant concentration about 200 ppm, which reached the value about $52.23 \%$ (Fig. 8). The effectiveness of the biosurfactant produced by $H$. meridiana BK-AB4 to inhibit the corrosion is better than the other published corrosion inhibitor, such as taxifolin [2]. Therefore, the biosurfactant produced by $H$. meridian $\mathrm{BK}-\mathrm{AB} 4$ has the potential to be developed as a substitute for non-environmentally friendly synthetic surfactants to overcome the problem of steel corrosion.

\section{CONCLUSION}

Halomonas meridiana BK-AB4 produced biosurfactant optimally in the medium containing $0.6 \%$ $(\mathrm{w} / \mathrm{v})$ urea and $2 \%(\mathrm{v} / \mathrm{v})$ palm oil as nitrogen and carbon sources. Produced biosurfactant from Halomonas meridiana BK-AB4 has a high potential to be further developed as a commercial corrosion inhibitor.

\section{ACKNOWLEDGEMENT}

This work is funded by ITB Research Grant with the contract number: 006g/l1.C01P/PL/2017.

\section{REFERENCES}

[1] Ochshorn, J., 2002, Steel in 20 $0^{\text {th }}$ Century Architecture. Encyclopedia of Twentieth Century Architecture, Fitzroy Dearborn Publishers, New York.

[2] Khandelwal, M., Sahu, S., Arora, S.K., and Mathur, S.P., 2013, A green approach for corrosion prevention, Int. J. Chem. Chem. Eng., 3 (3), 197200.

[3] Elmsellem, H., Aouniti, A., Hfid, Y.M., Bendaha, H., Hadda, T.B., Chetouani A., Warad, I., and Hammouti, B., 2013, Caffeine as a corrosion inhibitor of mild steel in hydrochloric acid, Phys. Chem. News, 70, 84-90.

[4] Tian, W., Yao, J., Liu, R., Zhu, M., Wang, F., Wu, X., Liu, H. 2016. Effect of natural and synthetic surfactants on crude oil biodegradation by indigenous strains, Ecotoxicol. Environ. Saf., 129, 171-179.

[5] Margesin, R., and Schinner, F., 2001, Potential of halotolerant and halophilic microorganisms for biotechnology, Extremophiles, 5 (2), 73-78.
[6] El-Sheshtawy, H.S., and Doheim, M.M., 2013, Selection of Pseudomonas aeruginosa for biosurfactant production and studies of its antimicrobial activity, Egypt. J. Pet., 23 (1), 1-6.

[7] Kłosowska-Chomiczewska, I.E., Mędrzycka, K., and Karpenko, E., 2011, Biosurfactantsbiodegradability, toxicity, efficiency in comparison with synthetic surfactants, Proceedings of the Polish-Swedish-Ukrainian Seminar, Krakow, Poland, 17-19 October 2011, 1-9.

[8] Hao, R., and Lu, A., 2009, Biodegradation of heavy oils by halophilic bacterium, Prog. Nat. Sci., 19 (8), 997-1001.

[9] Asy'ari, M., Parwata, I.P., Aditiawati, P., Akhmaloka, A., and Hertadi, R. 2014, Isolation and identification of halostable lipase producing bacteria from the bledug Kuwu mud crater located at Puwodadi-Grobogan, Central Java, Indonesia, J. Pure Appl. Microbiol., 8 (5), 3387-3396.

[10] Satpute, S.K., Bhawsar, B.D., Dhakephalkar, P.K., and Chopade, B.A., 2008, Assessment of different screening methods for selecting biosurfactant producing marine bacteria, Indian J. Mar. Sci., 37 (3), 243-250.

[11] Migahed, M.A., Attya, M.M., Rashwan, S.M., Abd El-Rouf, M., and Al-Sabagh, A.M. 2013, Synthesis of some novel non ionic surfactants based on tolyriazole and evaluation their performances as corrosion inhibitors for carbon steel, Egypt. J. Pet., 22, 149-160.

[12] Shukla, S.K., and Ebenso, E.E., 2011, Corrosion inhibition, adsorption behavior and thermodynamic properties of streptomycin on mild steel in hydrochloric acid medium, Int. J. Electrochem. Sci., 6 (8), 3277-3291.

[13] Solehudin, A., Berman, E.T., and Nurdin, I., 2015, Study of caffeine as corrosion inhibitors of carbon steel in chloride solution containing hydrogen sulfide using electrochemical impedance spectroscopy (EIS), AIP Conf. Proc., 1677, 070025.

[14] Putri, M., and Hertadi, P., 2015, Effect of glycerol as carbon source for biosurfactant production by halophilic bacteria Pseudomonas stutzeri BKAB12, Procedia Chem., 16, 321-327.

[15] Patowary, K., Patowary, R., Kalita, M.C., and Deka, S., 2017, Characterization of biosurfactant produced during degradation of hydrocarbons using crude oil as sole source of carbon, Front. Microbiol., 8, 279.

[16] Mohajeri, E., and Noudeh, G.D., 2012, Effect of temperature on the critical micelle concentration and micellization thermodynamic of nonionic surfactants: Polyoxyethylene sorbitan fatty acid esters, E-J. Chem., 9 (4), 2268-2274. 